\title{
Cultivation Practices of Mango (Mangifera indica) Varieties Kent and Keitt Planters and the Origins of Orchard Vulnerability to Rainfall Variability in the Koulikoro District
}

\author{
Samassé Diarra ${ }^{1,}$, , Sory Sissoko², Mamadou Oumar Diawara², Bakary Mamourou Traore', \\ Abdoulaye Sidibe ${ }^{1}$ \\ ${ }^{1}$ Department of Education and Research of Agricultural Sciences and Techniques, Rural Polytechnic Institute of Formation and Applied \\ Research of Katibougou, Koulikoro, Mali \\ ${ }^{2}$ Department of Education and Research of Biology, University of Sciences, Techniques and Technologies of Bamako, Bamako, Mali
}

Email address:

diarrasamasse@yahoo.fr (S. Diarra), sorysis@yahoo.fr (S. Sissoko),diaprod@hotmail.com (M. O. Diawara), abdoulayesidibe@yahoo.fr (A. Sidibe)

*Corresponding author

\section{To cite this article:}

Samassé Diarra, Sory Sissoko, Mamadou Oumar Diawara, Bakary Mamourou, Traore Abdoulaye Sidibe. Cultivation Practices of Mango (Mangifera indica) Varieties Kent and Keitt Planters and the Origins of Orchard Vulnerability to Rainfall Variability in the Koulikoro District. International Journal of Agricultural Economics. Vol. 6, No. 4, 2021, pp. 172-180. doi: 10.11648/j.ijae.20210604.14

Received: July 11, 2021; Accepted: July 26, 2021; Published: August 2, 2021

\begin{abstract}
Malian economy is largely based on agriculture, with mango being one of the country's main agricultural exports. The Koulikoro District is one of the main mango production areas in Mali. The sector is subject to numerous challenges, including vulnerability to rainfall variability. The objective of this study was to document the vulnerability of orchards, particularly those based on the Kent and Keitt varieties, in relation to cultivation practices. The approach used to document this issue was based on surveys and interviews with mango farmers of the Kent and Keitt varieties, to identify cultivation practices and the origins of the vulnerability of orchards to rainfall variability in the district. The results show that mango plantations are mainly managed by young, illiterate people, whose age range is $41-46$ years. The orchards are small, with areas ranging from 0.25 ha to 3.00 ha, half of which are located on gravelly soils. Women are very poorly represented $(6.52 \%$ of the sample) in this production activity. Mango seedlings are generally planted during the rainy season, with a high vegetative recovery rate at the start, but a very low survival rate in the months and years following the vegetative recovery. Water sources are traditional wells and streams (temporary and permanent). Manual watering is practiced by more than $80 \%$ of farmers. To conserve soil moisture, farmers mulch with or without basins under the mango trees. The lack of technical assistance and rainfall are the major constraints identified. Traditional water sources, primitive watering methods and poor moisture conservation techniques are factors that increase the vulnerability of orchards to rainfall variability.
\end{abstract}

Keywords: Kent, Keitt, Koulikoro, Mango Tree, Farmers, Orchards, Vulnerability

\section{Introduction}

Agriculture is the main activity of the population in Koulikoro district. Horticulture is one of the sectors that focuses on the production of fruits and vegetables. The quantities of mangoes sold or consumed by the farmers themselves are increasing from year to year. Mangoes are generally food products with high nutritional and commercial value [1]. They contribute to the improvement of social welfare and health status of the populations [2]. In addition, mango trees are an important component of agrarian space and land management [3].

Of all Malian horticultural production, the mango is the first fruit exported in Mali; it brings a significant surplus to the national economy with a contribution of more than 21 billion CFA francs $[4,5]$.

Mali is among the ten largest mango producing countries in the world [4]. The potential for fresh mango 
production in Mali is estimated at 575,000 tons [5]. According to FAOSTAT, production increased from 48,943 tons in 2008 to 52,708 tons in 2013 [6]. The main mango production basins are the Sikasso region; the largest and most productive region in the country, the Koulikoro region and periphery, the Bamako district and surrounding areas but also the Kayes region. Production is generally performed by small owners of small orchards with areas between 2 and 3 ha for the most part traditional. However, for less than 15 years, there have been large orchards in the Sikasso region, ranging in size from 50 to 100 ha. The mango is marketed mainly within the country of Mali, but also in Africa and Europe. Despite the great varietal diversity (nearly 100 varieties), only six of them (Kent, Keitt, Amélie, Tommy Atkins, Palmer and Valencia) are prized and exported in large quantities outside Mali [5]. In the Koulikoro mango production basin, planting activity is mostly based on the Floridian varieties Kent and Keitt, which are well appreciated outdoors but are subject to multiple cultivation technique problems [5]. In order to better promote the growth and development of Kent and Keitt varieties in the context of rainfall variability, it is necessary to have accurate and up-to-date information specific to these varieties. This study is part of this framework and aims to document the vulnerability of orchards, particularly those based on Kent and Keitt varieties, in relation to cultivation practices. The approach developed is based on surveys and interviews with farmers of the Kent and Keitt mango varieties in nine communes of the Koulikoro district.

\section{Materials and Methods}

\subsection{Study Area}

The District of Koulikoro is a territorial community of Mali with nine communes. The surveys concerned all the districts of the Koulikoro district, which are Koulikoro urban commune $\left(12^{\circ} 51^{\prime} 56^{\prime \prime} \mathrm{N}, 7^{\circ} 34^{\prime} 11^{\prime \prime} \mathrm{W}\right)$, the rural communes of Dinandougou ( $\left.13^{\circ} 10^{\prime} 52^{\prime \prime} \mathrm{N}, 7^{\circ} 06^{\prime} 22^{\prime \prime} \mathrm{W}\right)$, Doumba $\left(12^{\circ}\right.$ $\left.01^{\prime} 34^{\prime \prime} \mathrm{N}, 8^{\circ} 07^{\prime} 12^{\prime \prime} \mathrm{W}\right)$, Koula $\left(13^{\circ} 07^{\prime} 00^{\prime \prime} \mathrm{N}, 7^{\circ} 39^{\prime} 00^{\prime \prime}\right.$ $\mathrm{W})$ Méguétan $\left(12^{\circ} 52^{\prime} 27^{\prime \prime} \mathrm{N}, 7^{\circ} 31^{\prime} 54^{\prime \prime} \mathrm{W}\right)$, Nyamina $\left(13^{\circ}\right.$ $\left.18^{\prime} 47^{\prime \prime} \mathrm{N}, 6^{\circ} 58^{\prime} 59^{\prime \prime} \mathrm{W}\right)$, Sirakorola $\left(13^{\circ} 17^{\prime} 00^{\prime \prime} \mathrm{N}, 7^{\circ} 34^{\prime}\right.$ $\left.00^{\prime \prime} \mathrm{W}\right)$, Tienfala $\left(12^{\circ} 44^{\prime} 10^{\prime \prime} \mathrm{N}, 7^{\circ} 45^{\prime} 01^{\prime \prime} \mathrm{W}\right)$, and Tougouni ( $\left(13^{\circ} 13^{\prime} 00^{\prime \prime} \mathrm{N}, 7^{\circ} 12^{\prime} 00^{\prime \prime} \mathrm{W}\right)$ (Figure 1).

Agriculture occupies about $90 \%$ of the population of the district. The main agricultural products are dry cereals (millet, sorghum, corn, etc.), rice, groundnuts, cotton, and vegetables (tomatoes, onions, shallots, etc.). In the district of Koulikoro, arboriculture (tree plantations) play an important role in the household economy, with a wide variety of fruit trees such as mango, papaya, guava, banana, cashew and citrus.

There are two climatic zones in the district: the Sudanian zone in the south, with rainfall ranging from 650 to $850 \mathrm{~mm}$ per year, and the Sahelian zone in the north, with average rainfall ranging from 450 to $650 \mathrm{~mm}$ per year. There is an important hydrographic network (rivers, ponds, and streams) in the district. The different types of soil in the district are mostly characterized by their poverty and acidity. The arable land is composed mainly of deep, fine silty soils and shallow soils. These are plains, suitable for irrigated crops and fruit growing. They are located on the alluvium of the Niger River or scattered in narrow valleys [7].

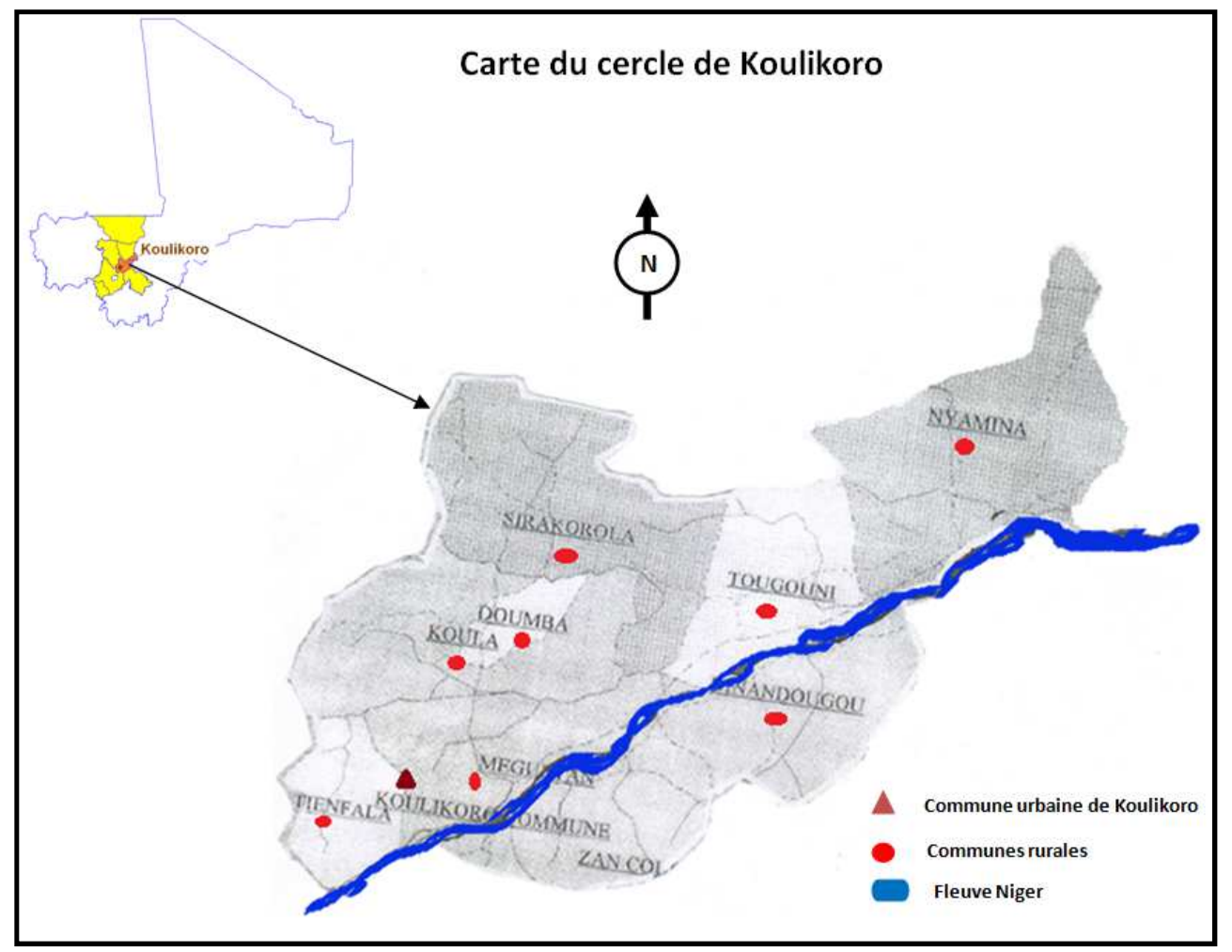

Figure 1. Map of the Koulikoro District [8]. 


\subsection{Plant Material}

It was composed of two varieties of mango: Kent and Keitt whose different characteristics are presented in Table 1.

Table 1. Main characteristics of the varieties Kent and Keitt.

\begin{tabular}{|c|c|c|c|c|c|c|}
\hline Variety & Origin & Fruit shape & Caliber & Coloration & Production period & Aspect and characteristics of the pulp \\
\hline Keitt & Floridian & Oval & $450-680 g$ & $\begin{array}{l}\text { Green yellow orange to } \\
\text { carmine pink }\end{array}$ & Late & $\begin{array}{l}\text { Orange to yellow relatively firm, melting, juicy, } \\
\text { with the presence of fibers not disturbing. }\end{array}$ \\
\hline Kent & Floridian & Ovoid \& Big & $750-800 g$ & $\begin{array}{l}\text { Greenish yellow colored } \\
\text { with red }\end{array}$ & End of mango season & $\begin{array}{l}\text { Intense yellow to orange yellow, melting without } \\
\text { fibers }\end{array}$ \\
\hline
\end{tabular}

Source: [9]

\subsection{Methodology}

\subsubsection{Criteria for Selecting the Sample}

The persons selected for the survey were chosen on the basis of the following criteria:

1. Be a planter of Kent and Keitt mango varieties in the Koulikoro district;

2. To own an orchard with Kent and Keitt varieties;

3. To belong to an association of mango planters in your commune);

4. Be available to participate in the study.

The respondents were selected by random draw from the commune's farmers' associations. A sample of 46 people was selected for the survey in the entire district. This means five people per rural commune and six people in the urban commune of Koulikoro.

\subsubsection{Questionnaire for the Survey of Kent and Keitt Planters in the Koulikoro District}

The questionnaire was administered in the form of interviews. The information collected included: the identity of the respondent (name, gender, age, level of education, main occupation), the mode of acquisition of the orchard (inherited, non-inherited), the age of the orchard, the soil types and the areas farmed, the cultivation practices for Kent and Keitt varieties (planting and management techniques adopted), and the main threats to the cultivation of Kent and Keitt varieties. The survey was composed of Open-ended questions, this has the advantage of allowing the respondent to give his/her point of view freely. The survey began each time with a briefing session on the objectives and methodology of the work at the level of each association concerned, in front of the association president and the village chief. The interview was conducted in the local language and according to the availability of the actors. The respondents answered the questions individually.

\subsubsection{Data Collection and Analysis}

Data for each survey worksheet were entered into Microsoft Excel 2013, then imported into IBM SPSS (Statistical Package for Social Science) version 25; with which the data was then analyzed to estimate nonparametric statistics, summaries into means, frequencies or percentages.

\section{Results}

\subsection{Characteristics and Status of Mango Farmers}

Table 2. Identification of planters in the different communes of Koulikoro Districts.

\begin{tabular}{lll}
\hline Variables & Number (n) & Percentage (\%) \\
\hline Gender & 43 & 93.48 \\
Men & 3 & 6.52 \\
Women & & \\
Age & 10 & 21.74 \\
35 - 40 years old & 29 & 63.04 \\
41 - 46 years old & 7 & 15.22 \\
+46 years old & & \\
Education level & 39 & 84.78 \\
Illiterate & 5 & 10.87 \\
Basic level & 2 & 4.35 \\
Medersa & & \\
Family size & 29 & 63.04 \\
5 - 10 persons & 10 & 21.74 \\
11 - 16 persons & 7 & 15.22 \\
+16 persons & & \\
Main occupation & 42 & 91.30 \\
Agriculture & 2 & 4.35 \\
Livestock & 1 & 2.17 \\
Fishing & 1 & 2.17 \\
Handicraft & & \\
\hline
\end{tabular}

Parameters such as gender, age, Education level, family size and main occupations of the surveyed farmers were identified (Table 2). The results showed that women are very poorly represented among the mongo planters, with only $6.52 \%$ of respondents. The arboriculture sector is strongly dominated by men in the Koulikoro district, affecting $93.48 \%$. The vast majority of mongo growers are young, with an age range of $41-46$ years $(63.04 \%)$, followed by an even younger age range of 35-40 years $(21.74 \%)$. These results indicate the motivation to plant Kent and Keitt varieties by young farmers in the different communes. The age group over 46 years is $15.22 \%$ (Table 2 ). The majority of mango farmers in the communes are illiterate (84.78\%); only $10.87 \%$ have reached the basic level and $4.35 \%$ have attended medersa (Table 2). The majority of the farmers surveyed have a very small family size (active and inactive), 5-10 persons, or $63.04 \%$; this result is explained by the high number of young people among the farmers. The number of families of $11-16$ persons is then, or $21.74 \%$, and the number of families of more than 16 persons is $15.22 \%$. Arboriculture 
is not the main activity of farmers in the zone. For the large majority of respondents, the main occupation remains cereal crops and vegetable growing $(91.30 \%)$; others have livestock raising $(4.35 \%)$, fishing $(2.17 \%)$ and handicrafts $(2.17 \%)$ as their main activity.

\subsection{Characteristics of Kent and Keitt Mango Orchards in the Koulikoro District}

\subsubsection{Mode of Acquisition of Orchards}

The results show that $80.43 \%$ of the orchards were created by the current owner, only $19.57 \%$ were inherited by the owners (Figure 2).

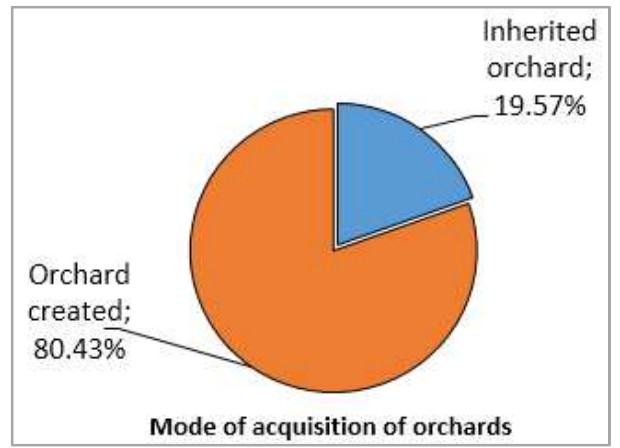

Figure 2. Mode of acquiring Kent and Keitt orchards in the Koulikoro district (2017).

\subsubsection{Age of the Orchards}

The largest number of orchards are in the 6-10 year old age group with $58.69 \%$, (Figure 3 ) followed by the $0-5$ year old age group $(26.08 \%)$ and finally the over 10 year old age group $(15.21 \%)$.

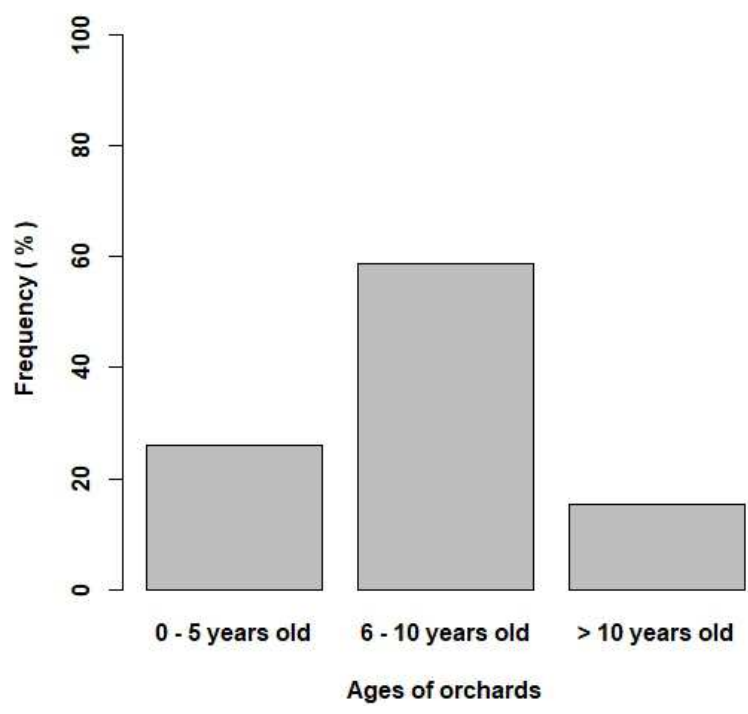

Figure 3. Ages of orchards in the district of Koulikoro (2017).

\subsubsection{Area of the Plantations (Orchards)}

Figure 4 shows us that more than $56 \%$ of the orchards surveyed have an area of half a hectare $\left(0.50 \mathrm{~m}^{2}\right)$, followed by $13 \%$ a quarter hectare $\left(0.25 \mathrm{~m}^{2}\right)$. We note that $6.52 \%$ of orchards have an area of 1 or 1.5 hectares and $8.69 \%$ have an area of 2 or more hectares.

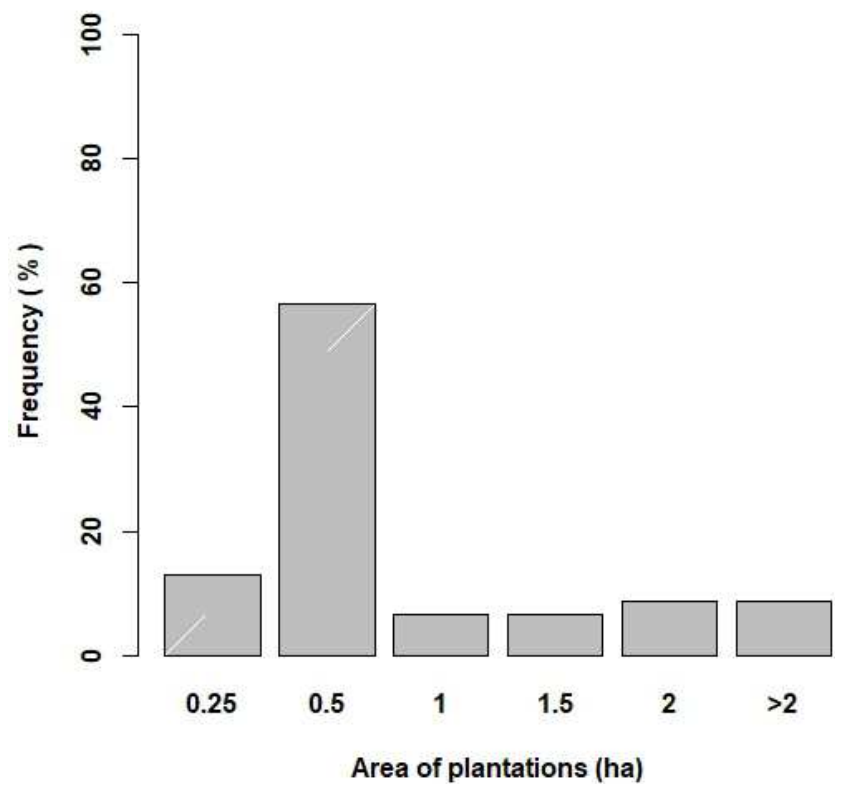

Figure 4. Area of plantations in the district of Koulikoro (2017).

\subsubsection{Soil Types of Orchards}

Gravel soils are dominant, with $50 \%$ of orchards planted on them (Figure 5). These soil types are the most available for planting fruit trees in the Koulikoro district. Only $15.22 \%$ of orchards are planted on clay soils. Generally, these soil types are used for cereal crops and vegetables.

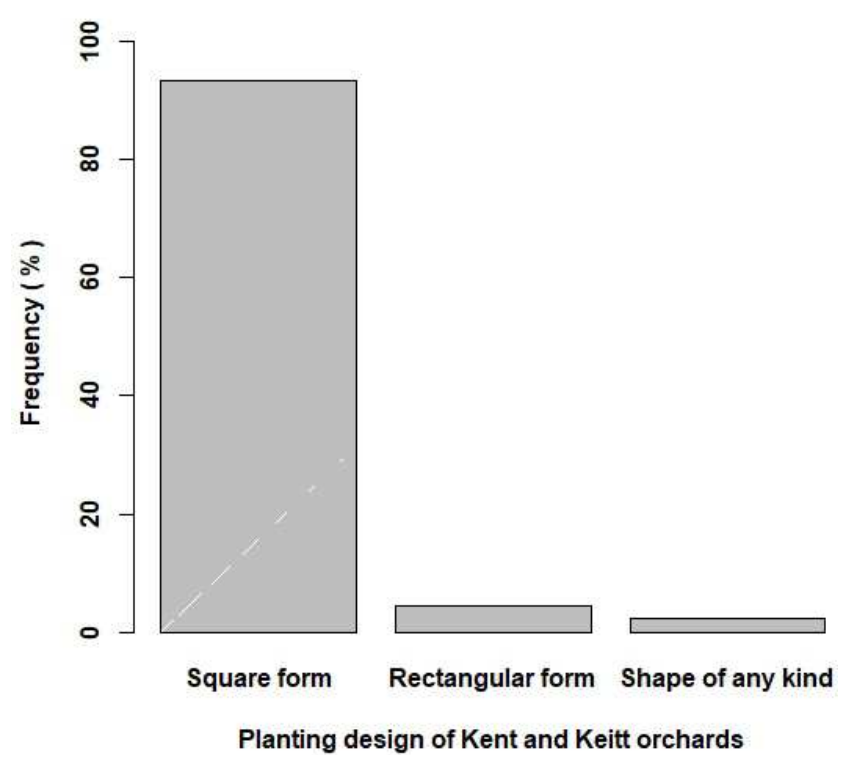

Figure 5. Type of soils used for orchards in the Koulikoro district (2017).

\subsection{Farming Techniques, of Kent and Keitt Mango Varieties, Applied by Farmers in the Koulikoro District}

\subsubsection{Planting Design or Shape of Orchards}

Three types of planting design (shapes) were observed. The square shape orchards are the most dominant with more than $93.48 \%$, followed by the rectangular shape $(4.35 \%)$ and finally the quelconque (no-form) shape represented $2.17 \%$ of the orchards visited (Figure 6). 


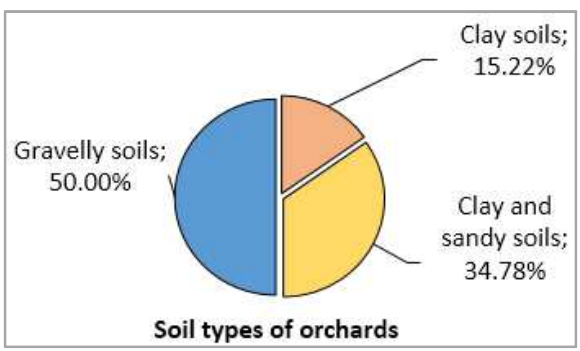

Figure 6. Planting design of Kent and Keitt orchards in the Koulikoro district 2017.

\subsubsection{Size of Planting Holes, Organic Manure Use and Planting Periods Adopted by Kent and Keitt Mango Farmers}

Mango seedlings are planted in holes of different sizes (depth and diameter) by farmers in the Koulikoro district. The results in Table 3 show that $58.70 \%$ of the planters adopted a holes depth of $40 \mathrm{~cm}$ with a diameter of $40 \mathrm{~cm}(40$ $\mathrm{cm} \times 40 \mathrm{~cm}$ ); the dimensions $50 \mathrm{~cm} \times 50 \mathrm{~cm}$ were adopted by $30.43 \%$ of the planters and $6.52 \%$ of the planters preferred holes size $30 \mathrm{~cm} \times 30 \mathrm{~cm}$. The study revealed that $4.35 \%$ of the planters do not know, with exactness, the depth and diameter of the holes for planting mango plants in their orchards.

After the setting of the holes, $82.61 \%$ of the farmers affirmed to use organic manure in the holes but none of them could quantify the dose of organic manure used, they all estimated that the holes were filled to $1 / 3$ with organic manure before the setting of the mango plants.

Four planting periods for mango seedlings were identified in this study. More than half of the planters of Kent and Keitt varieties of mango trees, i.e. $52.17 \%$, carry out their plantation during the rainy season, precisely in August, when it rains abundantly. The beginning of the rainy season was preferred by $26.09 \%$, while $19.57 \%$ of farmers planted mango seedlings in the cool dry season and $2.17 \%$ planted during all periods of the season (Table 3).

Table 3. Planting holes sizes, organic manure use, and planting periods adopted by Kent and Keitt mango farmers in the Koulikoro district in 2017.

\begin{tabular}{lll}
\hline Variables & Number (n) & Percentage (\%) \\
\hline Depth x Diameter & & \\
$30 \mathrm{~cm}$ x $30 \mathrm{~cm}$ & 3 & 6.52 \\
$40 \mathrm{~cm}$ x $40 \mathrm{~cm}$ & 27 & 58.70 \\
$50 \mathrm{~cm}$ x $50 \mathrm{~cm}$ & 14 & 6.52 \\
Not specified & 2 & 4.35 \\
Organic manure use & & \\
Yes & 38 & 82.61 \\
No & 8 & 17.39 \\
Planting periods & & \\
Cool dry season & 9 & 19.57 \\
Beginning of rainy season & 12 & 26.09 \\
In the middle of the rainy season & 24 & 52.17 \\
All periods of the season & 1 & 2.17 \\
\hline
\end{tabular}

\subsection{Sources (Origins) of Kent and Keitt Mango Seedlings}

The mango plantations in the Koulikoro district are made up of young plants from nurseries. Three main sources of Kent and Keitt seedlings were identified during the survey.
The results in Figure 7 show that $52.17 \%$ of seedlings come from local grafters (nurserymen); $26.09 \%$ of producers produce their own seedlings in their nurseries and do the grafting. Only $21.73 \%$ of producers obtain seedlings from the Genetic Resources Unit (URG) of the IER, an agronomic research structure based in Bamako.

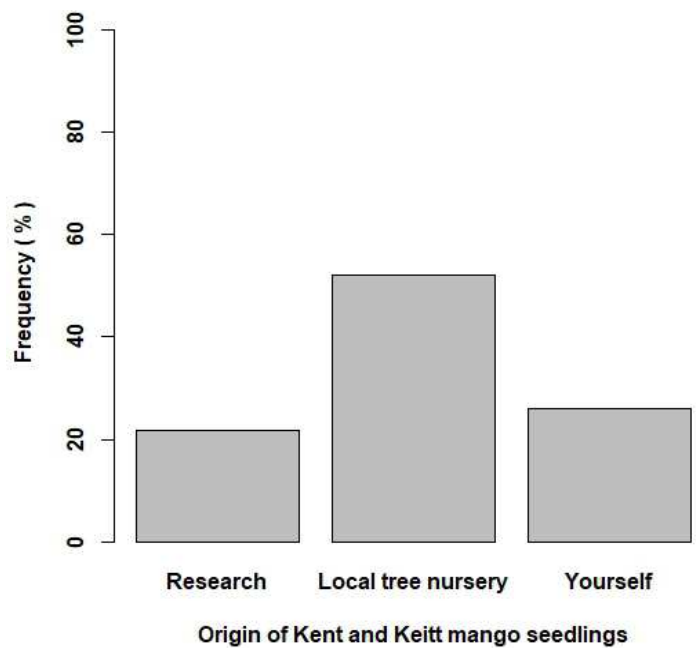

Figure 7. Sources (origin) of Kent and Keitt mango seedlings in the Koulikoro district in 2017.

\subsection{Rate of Vegetative Recovery of Seedlings Just After Planting and Survival Rate of Mango Trees at the Beginning of the Plantation}

A very good vegetative recovery rate of mango seedlings (between $91-100 \%$ ) is obtained by more than half of the farmers $(60.87 \%)$. Only $2.17 \%$ of the planters have a recovery rate between $40-50 \%$ (Figure 8 ). In contrast to the recovery rate, the survival rate in the months or years following the vegetative recovery is low; $91-100 \%$ survival rate is obtained by very few farmers $(4.35 \%)$ and $58.70 \%$ obtained a survival rate between $40-50 \%$ (Figure 8 ).
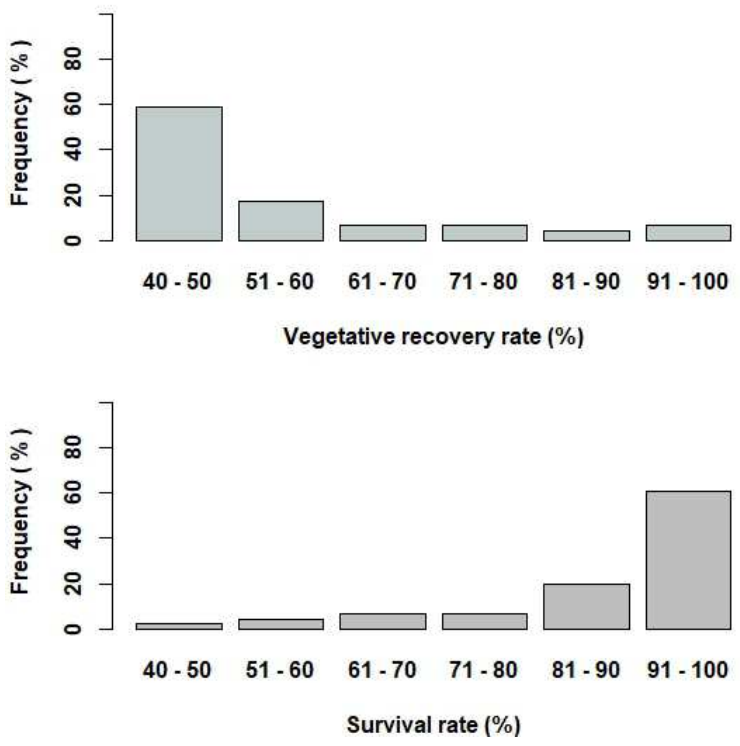

Figure 8. Vegetative recovery rate of seedlings after planting and survival rate at the beginning of the plantation in the Koulikoro district in 2017. 


\subsection{Association of Mango Trees with Other Crops at the Beginning of Plantation}

Annual intercrops (in the inter-rows) are planted during the first years of plantation by $91.30 \%$ of the farmers in the district (Figure 9). These crops are mainly cereals (millet, sorghum, maize), groundnuts, cowpeas or vegetables etc.

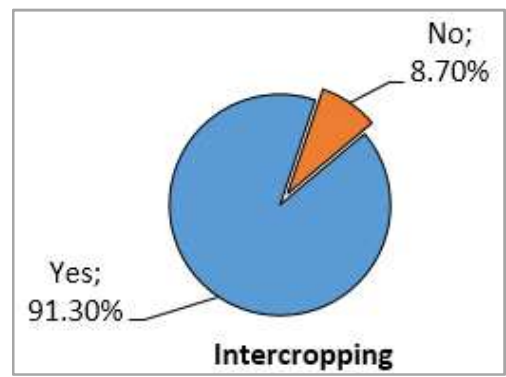

Figure 9. Planting of seedlings at start-up in association with other crops in the Koulikoro district in 2017.

\subsection{Management Techniques Applied at the Beginning of the Plantation in Mango Orchards}

\subsubsection{Water Sources at Plantation Establishment}

Traditional wells are the dominant water sources in the Koulikoro district, with $45.65 \%$ of growers using water from these wells at the start of mango planting; followed by water from temporary and permanent water courses used by $36.96 \%$ of planters. Only $13.04 \%$ of planters use boreholes (drilling) as a water source (Table 4). Of the five water sources listed by the farmers, four depend directly on rainfall and these four represent $87 \%$ of the water sources used at the start of mango planting in the Koulikoro district. This situation may be one of the causes of the vulnerability of mango orchards to rainfall variability in the Koulikoro district.

\subsubsection{Watering System (Irrigation)}

A watering system for mango seedlings at the start of planting is rudimentary and practiced by all mango planters in the Koulikoro district. The results in Table 4 show that $80.43 \%$ of planters irrigate the orchards manually at the beginning of the plantation. The gravity irrigation system is used by $15.22 \%$ and sprinkling by only $4.35 \%$ of planters. The use of a rudimentary (manual) irrigation system for orchards by the most of the planters can be cited among the factors that make orchards vulnerable to rainfall variability in the Koulikoro district.

\subsubsection{Soil Moisture Conservation Practices Adopted at the Start of Planting}

The various practices of conservation of the humidity of the soil are mentioned by the planters, the most used practices are: the mulching without basin practiced by $15.21 \%$ of the planters of the sample and basin plus straw practiced by $10.87 \%$. The use of straw or mulch avoids the drying of the soil, inhibits the growth of weeds and improves the soil's organic matter content when it is rotten. This mulching technique can be considered as a form of resilience to rainfall variability.

It was shown that the large majority of growers (45\%) remain inactive, not applying any technique to conserve soil moisture. This behavior could also be one of the reasons for the vulnerability of mango orchards to rainfall variability.

Table 4. Water sources, watering system and soil moisture conservation practices adopted at initiation of mango orchards in Koulikoro district.

\begin{tabular}{lll}
\hline Variables & Number (n) & Percentage (\%) \\
\hline Water sources & & \\
Traditional wells & 21 & 45.65 \\
Temporary water courses & 1 & 2.17 \\
Permanent water courses & 1 & 2.17 \\
Temporary water courses + permanents & 17 & 36.96 \\
Boreholes (drilling) & 6 & 13.04 \\
Watering system & & \\
Manual & 37 & 80.43 \\
Gravitational & 7 & 15.22 \\
Aspersion (Sprinkler) & 2 & 4.35 \\
Soil moisture conservation practices & & \\
End of rainy season plowing & 3 & 6.62 \\
Basin construction & 4 & 8.70 \\
Mulching without a basin & 7 & 15.22 \\
Basin + Straw & 5 & 10.87 \\
Storage tank & 3 & 6.62 \\
Well + pipe (motor pump) & 3 & 6.62 \\
No practice & 21 & 45.65 \\
\hline
\end{tabular}

\subsubsection{Protection and Other Management of Seedlings at the Start of the Plantation}

All farmers fence their plantations (Table 5) either with wire fencing or with living hedges of thorny plants, Jatropha curcas, etc., to protect the young seedlings from animals and people with bad intentions.

The results in Table 5 indicate that phytosanitary treatment is applied by all the farmers $(86.96 \%)$ especially in the context of soil treatment (planting holes) before or during the planting of mango seedlings to protect them from termites and other pests. But during the vegetative growth phase of the young plants, no phytosanitary protection is applied against pests.

At the end of the rainy season or during the dry season, all respondents practiced weeding between the rows (Table 5), either mechanically or manually. This practice prevents the spread of small rodents and termites, and also avoids fires in the plot. The planters all stated that they do not specifically apply chemical fertilizers at the start of planting.

Table 5. Protection and other management of seedlings at the start of mango planting in the Koulikoro district in 2017.

\begin{tabular}{lll}
\hline Variables & Number (n) & Percentage (\%) \\
\hline Fencing of orchard & 46 & 100 \\
Yes & 0 & 0 \\
No & & \\
Phytosanitary protection & 40 & 86.96 \\
Yes & 6 & 13.04 \\
No & & \\
Weeding between rows & 46 & 100 \\
Yes & 0 & 0 \\
No & & \\
Use of chemical fertilizers & 0 & 0 \\
Yes & 46 & 100 \\
No & & \\
\hline
\end{tabular}




\subsection{Constraints to Starting the Plantation of Kent and Keitt Mango Varieties in the Koulikoro District}

Farmers reported four constraints to starting seedling planting. Two constraints were major (Figure 10): the insufficiency of new technical guidance for adaptation to rainfall variability, reported by nearly $60 \%$ of planters, and the decreased (lack of) rainfall reported by nearly $35 \%$ of planters. These two constraints can also be cited as the main factors in the vulnerability of mango orchards to rainfall variability in the Koulikoro district.

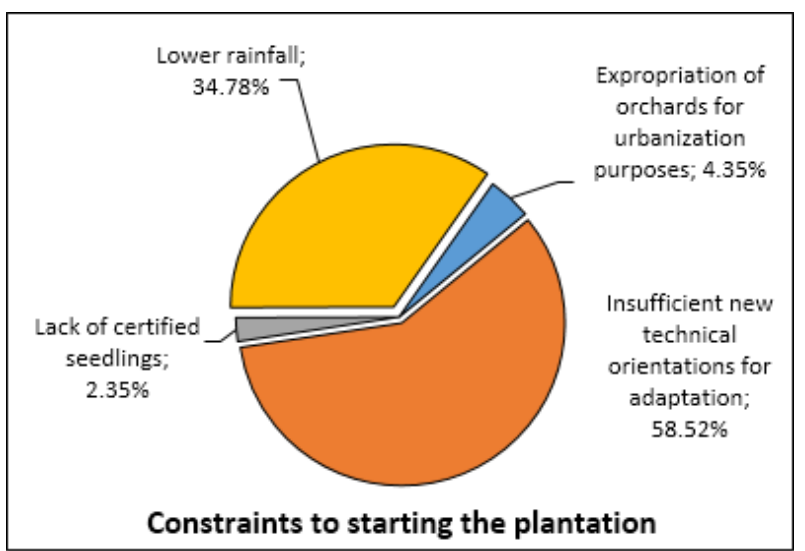

Figure 10. Constraints to starting the plantation of Kent and Keitt mango varieties in the Koulikoro district 2017.

\section{Discussion}

The survey of Kent and Keitt mango planters in the Koulikoro district revealed a high rate of young Kent and Keitt mango planters compared to those over 50 years old. More than $63 \%$ of the planters are in the $41-45$ age group. Young farmers are motivated to plant these two varieties. These results are essentially identical to those obtained by RSKB who obtained a majority age range of planters in their study between 40 and 44 years old [10]. Bama found a result opposite to ours in Burkina Faso, he obtained a high rate of elderly planters $(86 \%)$ among cashew and mango plantation owners, which reflects the difficulties of young people to access land in Burkina Faso [11]. Fruit growing is heavily dominated by men in the Koulikoro district; in our study, over $93 \%$ of mango planters were men. The same finding is made by Bama in Burkina Faso where male landholders were $84.54 \%$ compared to $15.46 \%$ women [11]. Sissoko et al. also reported the lack of women's land and equipment on farms in Mali [12]. The main mode of land acquisition in Africa is by inheritance, there is also donation or purchase [13]. In Mali, $75.4 \%$ of agricultural land is allocated through a rather informal system of inheritance [14]. While under traditional rules in many African countries, few women can acquire land through purchase, gift or inheritance [15]. The mode of acquisition by inheritance favors men, who are expected to keep the property in the family, over women who are expected to marry [14]. The majority of the farmers surveyed were illiterate $(84.78 \%)$ with agriculture as their main activity $(91.30 \%)$. According to a report by MA the practice of agriculture in Mali is characterized by a low level of education of the heads of households with only about $12 \%$ of the heads of households having attended formal school [14].

This study allowed us to identify two modes of acquisition of mango orchards in the Koulikoro district: the mode of creation of the plantation which concerned $80.43 \%$, against $19.57 \%$ acquired by inheritance by the owners. And the age of the largest number of orchards is between $6-10$ years $(58.69 \%)$ and only $15.21 \%$ of orchards are older than 10 years. Bama indicates that in Burkina Faso, $86 \%$ of planters inherited their mango plantations and the minimum age of the orchards is 4 years and 45 years the maximum [11].

In the district of Koulikoro, the majority of orchards are located on gravelly soils (50\%), with clayey-sandy soils at $34.72 \%$ and only $15.22 \%$ on clayey soils. Very heavy soils with high clay content should be avoided, as well as sandy soils [16].

Several cultivation techniques for Kent and Keitt mango varieties adopted by farmers in the Koulikoro district were revealed, including the size of planting holes, the use of organic manure and the planting periods adopted by farmers. Planters adopt different sizes of planting holes for seedlings. According to Telemans, the distance between trees in an orchard can vary depending on the varieties used, climate, soil, etc [16]. In our study, the majority of the holes used were $40 \mathrm{~cm}$ deep and $40 \mathrm{~cm}$ in diameter $(40 \mathrm{~cm} \mathrm{x} 40 \mathrm{~cm})$; this size concerned $58.70 \%$ of the planters. Organic fertilizers are applied to the holes at the start of planting to promote tree growth. Four planting periods for mango seedlings were identified during this study. Approximately $52 \%$ of the planters planted seedlings in the middle of the rainy season, precisely in August, so that the seedlings benefit from the rains during this period. As pointed out by Arbonnier, the mango tree requires humid and warm conditions to grow [17]. The study revealed that $91.30 \%$ of the farmers combine young mango trees with other crops in their orchards at the beginning of planting. This practice is confirmed by Tandjiekpon who reports that when the mango plantation is still young (before fruiting), intercropping can be considered and this situation is beneficial to the trees through the tillage and amendments that are made [18].

The water sources at the start of planting and the watering system for orchards in the Koulikoro district are rudimentary. Traditional wells and temporary and permanent rivers are the most common sources of water used by planters. These two sources account for more than $82 \%$. Manual watering is also used by more than $80 \%$ of planters at the start of the plantation. These rudimentary watering techniques were also reported by Vannière et al. in francophone West Africa; they report that watering of young plants during the first two years is a widely used and indispensable practice, with water often carried in buckets or in tanks pulled by donkeys to water the orchards [19].

The mango tree is grown in a hot and dry climate. Irrigation is essential for rapid establishment during the first few years after planting, and for regular production of high 
yields thereafter. An irrigation system that is compatible with the farm and water availability, must be chosen [16].

The soil moisture conservation practices most commonly adopted by planters at the start of planting in the Koulikoro district are mulching without basins, basins with straws, and the making of simple basins around the young plants. These three practices concern about $35 \%$ of the farmers in the district. The use of straw in orchards is widespread in West Africa. To limit evaporation, a little straw is spread around the plant. However, mulching increases the risk of fire and termite attack [19]. The study revealed that a large majority (45\%) did not apply any practices to conserve moisture to seedlings at initiation.

According to the survey results, more than half (60.87\%) of the growers achieve a very good survival rate after planting the seedlings, i.e. a survival rate of $90-100 \%$. But only $6.52 \%$ of the growers achieve $90-100 \%$ survival rate in the months or year after the seedlings recover. The low survival rate obtained at the beginning is mostly related to the decrease in rainfall, the absence of moisture conservation techniques and the time of planting of the seedlings. Trees planted in May or June manage to get through the following dry season without suffering too much. The same is not true for seedlings planted at the end of the rainy season [19].

Insufficiency of new technical adaptation guidelines, reported by nearly $60 \%$ of growers, and reduced rainfall, reported by nearly $35 \%$ of growers, were the two major constraints to the start of planting in the Koulikoro district. These constraints were also cited by Thiam et al. in "Capitalization study of information on the fruit and vegetable sector in Mali" [20].

The origins of the vulnerability of mango orchards to rainfall variability in the Koulikoro district are multiple. The survey discovered, among other things, the lack of literacy among planters, the lack of a modern water source (problem of water availability), the use of a primitive irrigation system, soil moisture conservation techniques adopted by very few planters, and insufficient advisory support (lack of supervision) in the orientation of new techniques for adaptation to climate change. Depending on the year, Sahelian farmers are increasingly confronted with either sudden stops in rainfall or excessive rainfall and flooding. The impacts of these extreme events are considerable and compromise the livelihoods of hundreds of millions of small farmers [21].

\section{Conclusion}

There is an enormous potential for growth in the mango production sector in Mali, but farmers face many constraints, especially in the establishment of orchards and the management of plantations. This study revealed that farmers of Kent and Keitt mango varieties in the Koulikoro district are mainly young people with a low percentage of female planters. The orchards are generally small in size and are mostly located on gravelly soil. Most of the water sources are traditional.

The cultivation practices are not too modern in the management of orchards. The literacy level of the farmers is almost the lowest. These factors can increase the vulnerability of orchards to rainfall variability. The major constraints confronting planters are socio-organizational (lack of supervision and advisory support, loss of orchards due to urbanization and the expansion of cities, etc.), climatic (reduced rainfall) and inadequate moisture conservation techniques under the seedlings. To overcome numerous constraints of Kent and Keitt mango planters in the Koulikoro district, it will be necessary to improve orchard management techniques by training planters and to provide them a modern irrigation system.

\section{Acknowledgements}

This study was supported by the Research Project funded by Rural Polytechnic Institute of Formation and Applied Research (IPR/IFRA) of Katibougou.

\section{References}

[1] PReSAN-KL. Preparatory studies for the formulation of the Project to Strengthen Food and Nutritional Security in the Koulikoro Region. 2014. 54 p.

[2] FAO. Production and nutritional values of tropical fruits. Online. URL:

http://www.fao.org/docrep/w1100f/W1100F00.htm\#Contents 2010. (Page visited on 03/03/2016).

[3] PCDA. Strategic development plan for the mango network in Mali. Minister of Agriculture. Final report. 2007. 40 pages.

[4] Haidara. Final national study on mango in Mali. 2012. 22 p.

[5] Diallo B, Coubaly J, Diarisso T, Staatz J, Traore A, Teme B. Development of the mango sector in Mali: Analysis of coordination and partnership models between different actors. 2016. 14 pages.

[6] FAOSTAT. FAO statistics for Mali in mango production. Minister of rural development. 2013. 3 p.

[7] PGRN-CC. (Project for the Management of Natural Resources and Climate Change in Mali). Environmental and Social Management Framework (CGES), Final Report. Agency for the Environment and Sustainable Development (AEDD). Minister of Environment and Assainissement of Mali. 2013.91 p.

[8] SRAT-Koulikoro. Regional Development Scheme of the Territory of the Koulikoro region. Final report. 2011. 121 p.

[9] Goguey T. and Fabrice L. B. Technical study of the mango sector in West Africa, sub-region Mali, Burkina Faso, Ivory Coast and Guinea, April-May 1995. Montpellier: CIRADFLHOR. 1995. 63 p.

[10] R-SKB, Technical and production statistics of the mango sector. IER Sikasso. 2017. 16 p.

[11] Bama Wend-Kuni J. Typology of mango and cashew agroforestry systems in the Kotoudeni (Kenedougou) area: impact on agricultural production. Master in management and development of forest ecosystems. Polytechnic University of Bobo-Dioulasso (UPB). 2017. 79 p. 
[12] Sissoko S., Diallo AG., Coulibaly SB., Teme N., Coulibaly MM., Vernon G., \& Danquah E. Farmers' Varietal Preferences And Implications In The Improvement Of Sorghum Productivity In Mali. Journal of Agriculture and Food Technology. 2016. 6 (3) 1-11. ISSN 2090 - 424X.

[13] GRAF. "Agribusiness in Burkina Faso: What effects on land tenure and agricultural modernization?" 2011. $77 \mathrm{p}$.

[14] MA. Agriculture and sources of income in Mali: an overview using data from the EAC-I 2017. Report by the Planning and Statistics Unit of the Rural Development Sector (CPS/SDR) of the Minister of Agriculture of Mali. 2019. 80 pages.

[15] UNFPA. "Diagnostic Analysis of the Situation of Women in Niger". Interim Report. 2000. 71 p.

[16] Telemans B. The cultivation of mango trees in Senegal. Center for the Development of Horticulture. Camberene - Dakar. Radhort - Publications. 2012. 12 p.

[17] Arbonnier M. "Trees, shrubs and lianas of the dry zones of
West Africa", CIRAD - MNHN - VICN, Montpellier (France). 2000. 541 p.

[18] Tandjiekpon. "Characterization of the cashew tree (Anacardium occidentale Linnaeus) agroforestry system in the savannah zone of Benin". 2005. 98 p.

[19] Vannière H., Didier C., Rey, JY., Diallo, TM., Kéita, K. and Sangaré M. Mango in Francophone West Africa: production systems and technical itineraries. Fruits. CIRAD/EDP Sciences. 2004. vol. 59, p. 383-398.

[20] Thiam AM, Haidara MF and Sidibé A. Capitalization study of information on the fruit and vegetable sector. Planning and Statistics Unit of Mali. 2001. 39 p.

[21] Boureima, M., Abasse, AT., Sotelo MC., Weber J. C., Katkoré B., Mounkoro B., Dakouo JM., Samaké O., Sigué H., Bationo, BA. and Diallo BO. Participatory analysis of vulnerability and adaptation to climate change: a methodological guide. Occasional Paper 19. Nairobi: World Agroforestry Centre. ICRAF-WCA/Sahel. 2012. 36 p. ISBN: 978-92-9059-315-7. 